\title{
Datalagring i medisinsk forskning
}

\author{
I den nye helseforskningsloven som trådte i kraft i 2009, heter det at helse- \\ opplysninger ikke skal oppbevares lenger enn det som er nødvendig for \\ å gjennomføre prosjektet. Dette innebærer at det blir nesten umulig å kon- \\ trollere om publiserte data er ekte eller fiktive. Det vil også være vanskelig \\ å kontrollere langtidsvirkninger av intervensjoner i medisinsk forskning.
}

\section{Arild Hals}

arild.hals@ntnu.no

Regional komité for medisinsk og helsefaglig forskning, Midt-Norge

Medisinsk teknisk forskningssenter

Norges teknisk-naturvitenskapelige universitet 7489 Trondheim

Hovedformålet med loven var å forenkle prosedyrene rundt godkjenning av forskningsprosjekter. Forskerne skal ha ett regelverk og én postkasse å forholde seg til, med noen unntak. De regionale komiteene for medisinsk og helsefaglig forskning har fătt en sentral posisjon og overtatt myndighet som tidligere har ligget f.eks. i Datatilsynet og Helsedirektoratet. Store deler av den nye loven innebærer likevel ikke store endringer av tidligere etiske og juridiske regelverk. Loven er en formalisering og tydeliggjøring av forhold som har vært fulgt tidligere. Den tydeliggjør bl.a. hvem som har et overordnet ansvar ved bruk av begrepet forskningsansvarlig. Institusjonene har i realiteten hatt det samme ansvar tidligere, men uten at det har vært lovfestet.

\section{Unødvendige helseopplysninger?}

En regel om lagring av unødvendige helseopplysninger er også tatt inn i loven. Nylenna-utvalget foreslo at den forskningsansvarlige skulle «sørge for at forskningsdata blir oppbevart og forvaltet forsvarlig og i minst 10 år etter avsluttet prosjekt» (1). Dette omhandler kildedata/grunnlagsmateriale som forskningsprosjektene er basert på, hvor det ofte er snakk om identifiserbare personopplysninger og helseopplysninger. Departementet fulgte ikke Nylenna-utvalgets forslag, men heller Datatilsynets forslag. Ordlyden i departementets forslag var som følger: Dersom det benyttes personidentifiserbare helseopplysninger, skal opplysningene avidentifiseres eller anonymiseres senest 30 dager etter at sluttmeldingen er sendt den regionale komiteen for medisinsk og helsefaglig forskningsetikk (2).

I departementets kommentarer til lov- teksten ble det slått fast at hovedregelen skulle være at opplysninger slettes. Dette er ikke begrunnet med noe annet enn en henvisning til helseregisterlovens $\S 27$. Slike krav har vært pålagt i mange sammenhenger både fra Datatilsynet og andre instanser og begrunnet ut fra personvernhensyn. Dette forslaget til lov ble tatt opp med stortingskomiteen og saksordfører for loven av representanter for Regional komité for medisinsk og helsefaglig forskning, Midt-Norge (REK Midt-Norge). De betenkelige momenter som et slikt krav skaper ble påpekt. Jeg vil belyse dette nærmere nedenfor.

\section{Kontroll av data}

Lagring er viktig for å kunne kontrollere bl.a. at det ikke er fusket med data og at det ikke er brukt falske pasienter. Dersom det i et forskningsprosjekt er nødvendig med 500 deltakere, men det synes vanskelig å få tak i de siste 150, vil det kunne være fristende å dikte opp disse. Videre er det tenkbart at man kan endre på pasientdata for å gjøre resultatene av studier mer interessante og lettere publiserbare. Dersom alle grunnlagsopplysningene skal slettes bare 30 dager etter at melding er sendt Regional etisk komité om avsluttet prosjekt, vil det være nesten umulig å kontrollere om data i den endelige studien representerer ekte eller fiktive forsøkspersoner og målingsresultater. Uredelighet og fusk er dessverre et reelt problem også i Norge, og ethvert tiltak som kan hindre dette er viktig og nødvendig.

\section{Pasientsikkerhet}

En viktig begrunnelse for oppbevaring av grunnlagsmateriale, særlig når det gjelder medikamentutprøvninger, er at det skal være mulig å kontrollere langtidsvirkninger av intervensjoner i medisinsk forskning. Det må være mulig å kunne gå tilbake og kontrollere f.eks. om deltakeren fikk placebo eller ikke. Et godt eksempel er den store vaksinasjonsstudien her i Norge for 20 år siden (3). Det ville være umulig å få svar på om det har vært langtidsvirkninger av denne vaksinasjonen dersom alt grunnlagsmateriale hadde vært slettet på en slik måte at enkeltindivider ikke kunne få stadfestet om de hadde fătt virksom vaksine eller ikke. I prinsippet må man ha mulighet til å sjekke om man har vært deltaker i medisinske forskningsprosjekter - det burde gjelde alle prosjekter, ikke bare medikamentutprøvninger. Det burde også være et krav om at pasienters deltakelse i forskningsprosjekter blir ført inn i deres sykejournaler.

\section{Gjenbruk av forskningsmateriale}

Innsamlet materiale kan også tenkes brukt i senere forskning. Det var nettopp ideen bak opprettelsen av Norsk samfunnsvitenskapelig datatjeneste i 1971. Selv om det ikke vil være så ofte at slik gjenbruk er mulig, så bør muligheten være til stede. Særlig vil dette gjelde når en forsker ønsker å bruke eget «gammelt» materiale. Det er ofte slik at jo eldre materialet blir, desto mer verdifullt vil det kunne være $\mathrm{i}$ vitenskapelig sammenheng.

\section{Rett til å oppbevare materiale?}

Loven setter regler for sletting av forskningsdata. Kanskje burde man heller snu på det og spørre om forskerne bør ha lovfestet rett til å oppbevare materialet. En forsker må kunne ha mulighet til å bevise at det som er publisert, er korrekt. Det vil være et vern mot falske påstander. Å bli pålagt å destruere materiale som kan være helt avgjørende for å vise at de resultater man har presentert er korrekte, må være både galt og uheldig.

\section{EU-direktiv}

Ifølge et EU-direktiv skal grunnlagsmaterialet i medikamentutprøvninger oppbevares minst fem år etter at et prosjekt er avsluttet (4). I forskrifter for utprøving av legemidler av 2009, § 8-2 er kravet til oppbevaring satt til 15 år (5). Forskning som ikke dreier seg om legemidler kan ha like stor betydning, like store og alvorlige følger for den praktiske pasientbehandlingen og det samme kontroll- og verifiseringsbehovet. Det er derfor ulogisk at det skal være forskjellige regler for medikamentutprøvning og annen forskning. Begrunnelsen for oppbevaring av grunnlagsmateriale i lengre tid er den samme uansett hvilken forskning det er snakk om.

\section{Endret lovforslag}

I loven som ble vedtatt av Stortinget er teksten endret i forhold til opprinnelig forslag: $\S 38$. Forbud mot lagring av unødvendige helseopplysninger. 


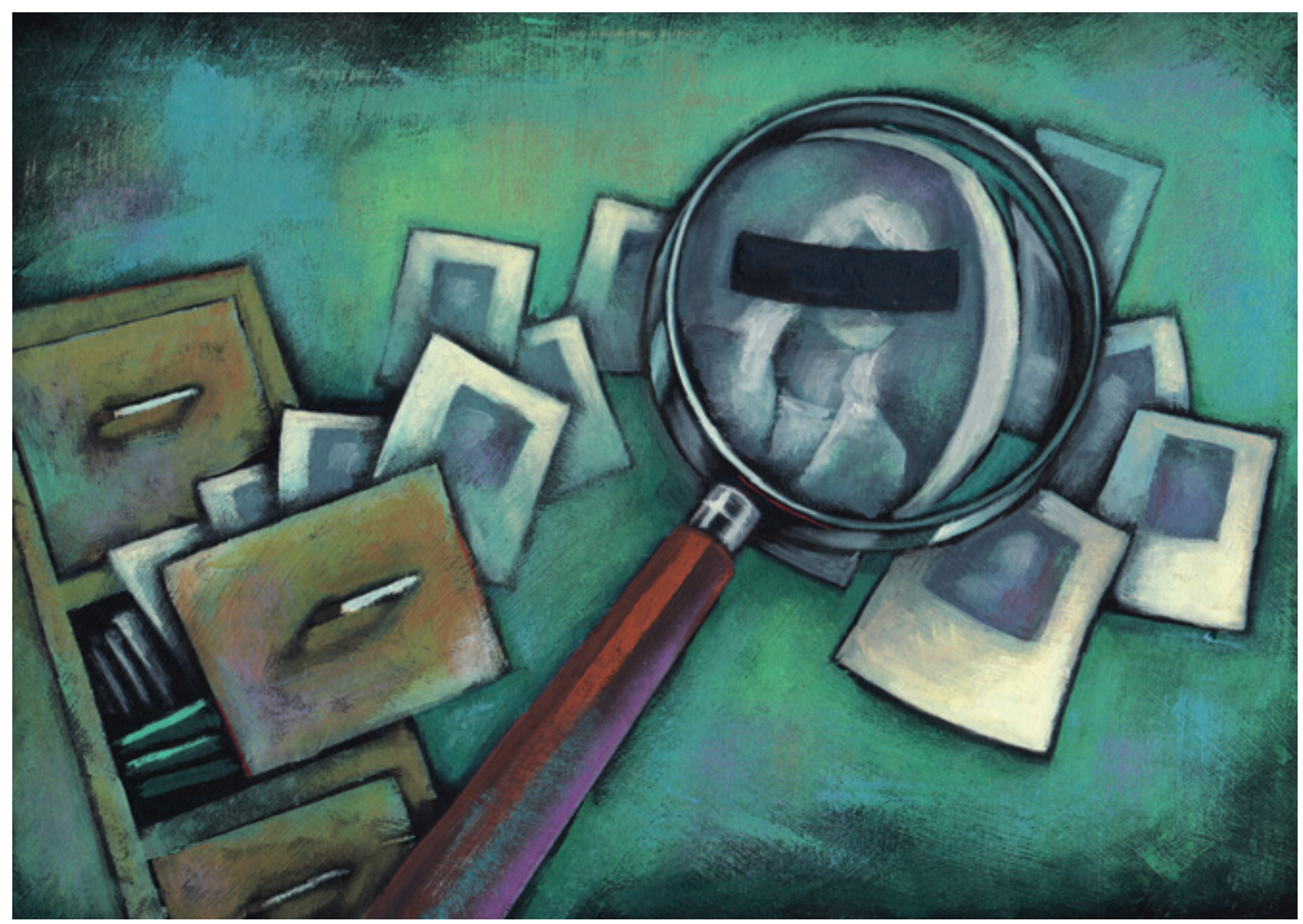

Illustrasjon Stein Løken

Opplysninger skal ikke oppbevares lenger enn det som er nødvendig for å gjennomfore prosjektet. Den regionale komiteen for medisinsk og helsefaglig forskningsetikk kan bestemme at dokumenter som er nødvendig for etterkontroll av prosjektet, skal oppbevares i fem år etter at sluttmelding er sendt komiteen. Hvis opplysninger ikke deretter skal oppbevares $i$ henhold til arkiv-

loven eller annen lovgivning, skal de anonymiseres eller slettes. Den regionale komiteen for medisinsk og helsefaglig forskningsetikk kan bestemme at opplysningene skal oppbevares $i$ lenger tid enn det som følger av første ledd. Til slikt vedtak kan knyttes vilkår (6).

Loven slik den ble vedtatt pålegger de regionale komiteer for medisinsk og helsefaglig forskning (REK) å vurdere om lagring av data er ønskelig og nødvendig. Praksis så langt tyder på at komiteene bruker denne lovparagrafen ulikt. REK Midt-Norge pålegger i realiteten alle å oppbevare sine grunnlagsdata i minst fem år. Komiteen finner det riktig å se alle prosjekter som prinsipielt like viktige. Fusk og uredelighet er like uakseptabelt $i$ en masteroppgave som i en stor internasjonal multisenterstudie. En klar forutsetning for dette er naturligvis at det opplyses i informasjonsskrivene til pasienter og deltakere at samtykke til slik oppbevaring er en forutseting for å kunne delta i prosjektet.

\section{Lovfestet krav til oppbevaring av kildedata?}

Jeg mener man bør vurdere en lovfestet plikt til å oppbevare grunnlagsmateriale. Hvor lenge og hvordan dette kan og bør gjøres må variere, fra prosjekt til prosjekt, men et minimum på fem år slik direktivet fra EU krever for medikamentutprøvning, bør være et godt utgangspunkt. Forskningsansvarlig institusjon må legge opp et system og en prosedyre for hvordan dette kan gjøres på forsvarlig vis.

\section{Personvern}

Begrunnelsen for krav om sletting av personidentifiserbare data har vært hensynet til personvernet. Dette er naturligvis viktig. Det er en selvfølge at slike data må behandles slik at de ikke kan komme på avveie eller misbrukes. Alle som kommer i kontakt med slike data, prosjektledere og medarbeidere, har lovpålagt taushetsplikt. Det er et særlig ansvar for den forskningsansvarlige institusjon å få etablert en prosedyre og et system for forsvarlig oppbevaring av forskningsdata. Helsevesenet oppbevarer i dag store mengder opplysninger av liknende karakter uten at dette byr på vesentlige problemer. I Nylennautvalgets innstilling ble det foreslått at «helseopplysninger med skjult identitet kan lagres i ubegrenset tid hos Arkivverket eller hos virksomhet som er tildelt databehandlings- ansvar i medhold av helseregisterloven $\S 8$ »» (7). Det synes rimelig at personidentifiserbare data knyttet til medisinsk og helsefaglig forskning kan lagres under disse betingelsene $i$ en tidsperiode som sikrer at alt behov for oppfølging er dekket.

\section{Oppgitte interessekonflikter: Ingen}

\section{Litteratur}

1. Norges offentlige utredninger. God forskning bedre helse, forslag til lov $\S 2-3$, side 224 . NOU 2005: 1

2. Ot.prp. nr. 74 (2006-2007). Om lov om medisinsk og helsefaglig forskning (helseforskningsloven), $\S 38$.

3. Kristiansen B, Brandtzæg P, Bjorvatn B et al. Meningokokkvaksineforsøket 1988-91. Tidsskr Nor Legeforen 2009; 129: 192-4.

4. Commission Directive 2005/28/EC of April 2005: laying down principles and detailed guidelines for good clinical practice as regards investigational medicinal products for human use, as well as the requirements for authorisation of the manufacturing or importation of such products. OJ L91/17 http://eur-lex.europa.eu/LexUriServ/ LexUriServ.do?uri=0 J:L:2005:091:0013:0019:en: PDF (23.3.2010).

5. FOR-2009-10-30-1321 Forskrift om klinisk utprøving av legemidler til mennesker

6. LOV-2008-06-20-44 Lov om medisinsk og helsefaglig forskning, § 38 .

7. Norges offentlige utredninger. God forskning bedre helse, § 7-8, side 229. NOU 2005: 1. 